\title{
KONSENTRASI IAA (Indole Acetic Acid) DAN BAP (Benzyl Amino Purine) PADA KULTUR JARINGAN ULIN (Eusideroxylon zwageri)
}

\author{
(Concentration of IAA (Indole Acetic Acid) and BAP (Benzyl Amino Purine) On Ulin \\ (Eusideroxylon zwageri) Tissue Culture)
}

\author{
Herni Wahyuni, Reine Suci Wulandari, Muflihati \\ Fakultas Kehutanan Universitas Tanjungpura, Jalan Imam Bonjol Pontianak, 78124 \\ E-mail: herniwahyuni18@gmail.com
}

\begin{abstract}
Ulin (Eusideroxylon zwageri) is a species of wood with high economic value that is difficult to find in the wild. Regeneration of E. zwageri is naturally very slow. Efforts to increase the procurement of E. zwageri seedlings can be done with a tissue culture technique. Through tissue culture, the seeds obtained will be uniform, have better quality and faster. This study aims to determine the effect and optimum concentration of IAA and BAP growth regulators on E. zwageri explants growth. The method used is experimental using a completely randomized design. Treatment factors are IAA concentration factor with 5 levels of treatment $(0 \mathrm{mg} / \mathrm{L}, 0.5$ $\mathrm{mg} / \mathrm{L}, 1 \mathrm{mg} / \mathrm{L}, 1.5 \mathrm{mg} / \mathrm{L}$, and $2 \mathrm{mg} / \mathrm{L})$ and BAP concentration of 5 treatment levels $(0 \mathrm{mg} / \mathrm{L}, 1$ $\mathrm{mg} / \mathrm{L}, 2 \mathrm{mg} / \mathrm{L}, 3 \mathrm{mg} / \mathrm{L}$, and $4 \mathrm{mg} / \mathrm{L}$ ). Each treatment was repeated 3 times. The results showed that the treatment of IAA concentration, BAP concentration and the interaction of IAA and BAP concentration affected the swelling of explants and growth of E. zwageri callus. The best concentration for callus explants was IAA of $2 \mathrm{mg} / \mathrm{L}$ and BAP of $0 \mathrm{mg} / \mathrm{L}$, with a time of 12-13 weeks after planting.
\end{abstract}

Keywords: BAP, E. zwageri, IAA, Tissue Culture

\section{PENDAHULUAN}

Ulin (Eusideroxylon zwageri) juga dikenal dengan nama belian dan kayu besi borneo (borneo iron wood) dan termasuk salah satu jenis pohon asli (indigeneous tree species) pulau Kalimantan. Ulin merupakan salah satu jenis kayu yang bernilai ekonomi tinggi yang memiliki kelas awet 1 dan kelas kuat I. Ulin dapat dikembangbiakkan dengan cara generatif maupun vegetatif. Secara generatif pembiakan ulin dapat dilakukan dengan biji namun perkecambahannya membutuhkan waktu yang cukup lama. Menurut Nurhasybi dan Sudrajat (2006), perkecambahan benih ulin kurang serempak dan memerlukan waktu yang cukup lama (6 -12 bulan), sedangkan kebutuhan kayu ulin setiap tahunnya sangatlah tinggi. Pengembangbiakan secara vegetatif adalah alternatif terbaik untuk menyediakan bibit ulin yang berkualitas. Salah satu pengembangbiakan secara vegetatif ulin yang dapat dilakukan yaitu kultur jaringan.

Kultur jaringan adalah teknik perbanyakan tanaman dengan mengisolasi bagian dari tanaman yang ditumbuhkan dengan kondisi aseptik sehingga bagian tanaman tersebut dapat memperbanyak diri tumbuh menjadi tanaman lengkap kembali. Kultur jaringan efektif menghasilkan bibit yang relatif lebih banyak dalam waktu 
yang lebih cepat dibandingkan dengan biji, serta menghasilkan anakan yang unggul seperti induknya. Penggunaan zat pengatur tumbuh dalam kultur jaringan tanaman sangat penting dalam pertumbuhan eksplan. Ada dua golongan zat pengatur tumbuh tanaman yang sering digunakan dalam kultur jaringan, yaitu sitokinin dan auksin (Lestari, 2011). Auksin banyak digunakan secara luas pada kultur in vitro dalam merangsang pertumbuhan kalus, suspense sel dan organ (Gunawan, 2008). Golongan auksin yang sering digunakan antara lain IAA, NAA, IBA, dan 2.4-D. Pemberian sitokinin ke dalam medium menyebabkan pembelahan sel dan diferensiasi tunas adventif dari kalus menjadi organ. Jenis sitokinin yang banyak digunakan pada kultur jaringan adalah BAP, 2-ip (N6-2-Isopentanyl adenin atau 6-(t,t-Dimetyl Allyl Amino Purine), dan kinetin (Zulkarnain, 2009).

Pemilihan jenis dan dosis yang tepat sangat menentukan keberhasilan perbanyakan tanaman dengan teknik kultur jaringan. Pada kadar rendah, hormon atau zat pengatur tumbuh akan mendorong pertumbuhan, sedangkan pada kadar yang lebih tinggi akan menghambat pertumbuhan, meracuni bahkan mematikan tanaman (Supriyanto dan Prakasa, 2011). IAA dan BAP merupakan golongan auksin dan sitokinin yang baik untuk merangsang pertumbuhan tunas, akar, serta kalus tanaman secara kultur jaringan. Namun pemberian IAA dan BAP pada eksplan biji ulin belum pernah dilakukan sebelumnya. Oleh karena itu perlu dilakukan penelitian ini untuk mengetahui konsentrasi IAA dan BAP terbaik untuk pertumbuhan eksplan ulin.

Penelitian bertujuan untuk mengetahui pengaruh dan konsentrasi optimum dari pemberian IAA dan BAP terhadap pertumbuhan eksplan ulin. Manfaat dari penelitian ini diharapkan dapat menjadi acuan dalam penyediaan bibit Ulin secara reproduksi vegetatif melalui teknik kultur jaringan, guna menunjang kegiatan pengadaan bibit berkualitas dan seragam dalam jumlah yang banyak dalam waktu yang relatif singkat.

\section{METODE PENELITIAN}

Penelitian dilaksanakan di Laboratorium Silvikultur Fakultas Kehutanan, Universitas Tanjungpura. Waktu penelitian selama 8 bulan dengan 5 bulan pengamatan. Alat yang digunakan adalah erlenmeyer, laminar air flow cabinet, gelas ukur, gelas piala, hot plate, botol kultur, autoclave, $\mathrm{pH}$ meter. Bahan yang digunakan dalam penelitian ini adalah biji ulin, media MS (hara makro, mikro, zat besi, gula, myoinositol, vitamin dan bubuk agar), larutan IAA, larutan BAP, bahan sterilisasi (alkohol, deterjen cair, betadine dan chlorox).

Penelitian ini dimulai dengan a.sterilisasi ruang kerja dan alat dengan menyemprotkan alkohol $70 \%$ keseluruh ruangan dua hari sebelum ruangan digunakan dan setiap pagi selama pengamatan. Sedangkan sterilisasi alat dilakukan dengan dua cara yaitu sterilisasi kering dengan oven 
dan sterilisasi basah menggunakan autoclave. b.pembuatan dan sterilisasi media tumbuh yaitu memasukkan aquades sebanyak $100 \mathrm{ml}$ kedalam gelas piala lalu menambahkan stok hara makro, mikro, zat besi dan vitamin, larutan IAA dan BAP sesuai dengan konsentrasi yang digunakan, gula halus 6 gram dan myo-inositol $20 \mathrm{mg}$. Aquades ditambahkan kedalam gelas piala sampai volume $200 \mathrm{ml}$, diaduk kembali larutan medianya sehingga homogen. Setelah itu, $\mathrm{pH}$ larutan media diukur sekitar 5,6-5,8 lalu memasukkan bubuk agar-agar sebanyak 2 gram kedalam gelas piala. Setelah larutan mendidih, larutan media MS dituangkan kedalam botol kultur dan media disterilkan menggunakan autoclave dengan tekanan 14.5 psi pada suhu $121^{\circ}$ C selama \pm 20 menit. c.sterilisasi bahan tanam dilakukan dengan (1) mencuci eksplan biji ulin dibawah air mengalir dengan diberi sedikit deterjen cair, (2) direndam dalam alkohol $70 \%$ selama 5 menit, (3) dibakar di atas lampu bunsen dan dikupas kulit luarnya, (4) biji direndam didalam larutan chlorox selama 10 menit lalu dibilas dan di rendam kembali dengan larutan chlorox selama 5 menit dan sampai bersih (5) setelah bersih eksplan di potong kecil dengan ukuran 1-2 cm dan dicelupkan kedalam betadine, kemudian ditiriskan dikertas saring dan ditanam di media tanam.

Metode yang digunakan adalah eksperimen dengan menggunakan rancangan acak lengkap 2 faktor yaitu faktor konsentrasi IAA dengan 5 taraf perlakuan $(\mathrm{A} 1=0 \mathrm{mg} / \mathrm{L}, \mathrm{A} 2=0,5$ $\mathrm{mg} / \mathrm{L}, \mathrm{A} 3=1 \mathrm{mg} / \mathrm{L}, \mathrm{A} 4=1,5 \mathrm{mg} / \mathrm{L}$ dan $\mathrm{A} 5=2 \mathrm{mg} / \mathrm{L}$ ) dan konsentrasi BAP (B1 $=0 \mathrm{mg} / \mathrm{L}, \mathrm{B} 2=1 \mathrm{mg} / \mathrm{L}, \mathrm{B} 3=2 \mathrm{mg} / \mathrm{L}$, $\mathrm{B} 4=3 \mathrm{mg} / \mathrm{L}$ dan $\mathrm{B} 5=4 \mathrm{mg} / \mathrm{L}$ ). Terdapat 25 perlakuan dengan tiga (3) kali ulangan. Variabel yang diamati yaitu pertumbuhan eksplan membengkak, pertumbuhan eksplan berkalus dan hari munculnya kalus Analisis data yang digunakan adalah Analisis Sidik Ragam (ANOVA) dan uji lanjut Beda Nyata Jujur (BNJ).

\section{HASIL DAN PEMBAHASAN}

Hasil pengamatan didapatkan $31 \%$ eksplan membengkak, $12 \%$ eksplan berkalus, dan $57 \%$ eksplan tidak mengalami pertumbuhan. Ajijah et al. (2010), mengatakan bahwa pembengkakan pada eksplan adalah tahap awal pembentukan kalus yang mengindikasikan adanya aktifitas sel pada eksplan. Menurut Zulkarnain (2009), kalus terbentuk dari keadaan dimana eksplan mengalami pelukaan pada proses penanaman, keadaan yang akan terjadi apabila kalus terbentuk yaitu pembengkakan dari eksplan tersebut.

\section{Eksplan Membengkak}

Pertumbuhan eksplan ulin diawali dengan pembengkakan eksplan dibagian yang bersentuhan dengan media dan diikuti dengan munculnya kalus yang nampak putih di permukaan atas eksplan (Gambar 1). 


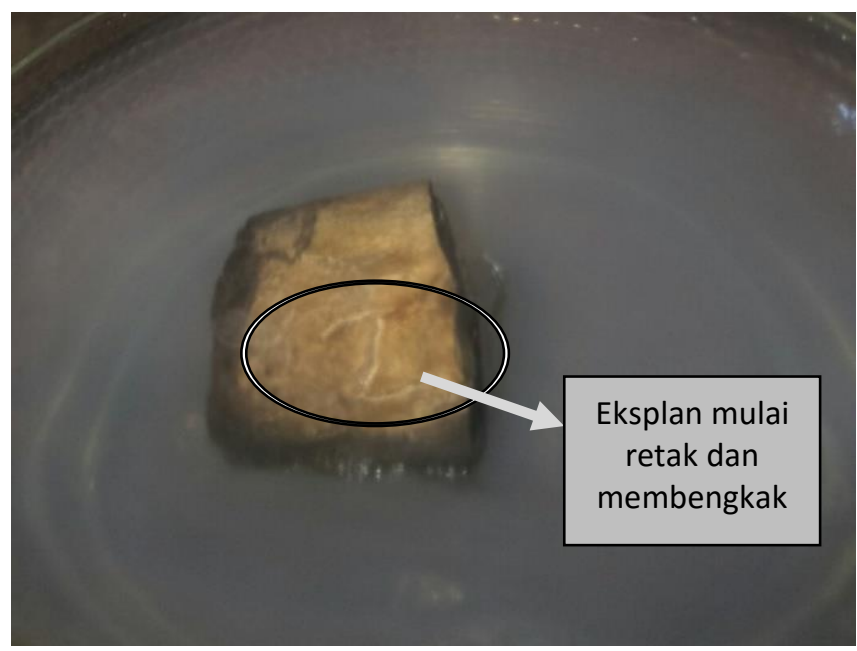

Gambar 1. Eksplan Mulai Membengkak (Explant began to swell)

Nilai rata-rata eksplan yang mengalami proses pembengkakan selama 20 minggu setelah tanam disajikan pada Gambar 2.

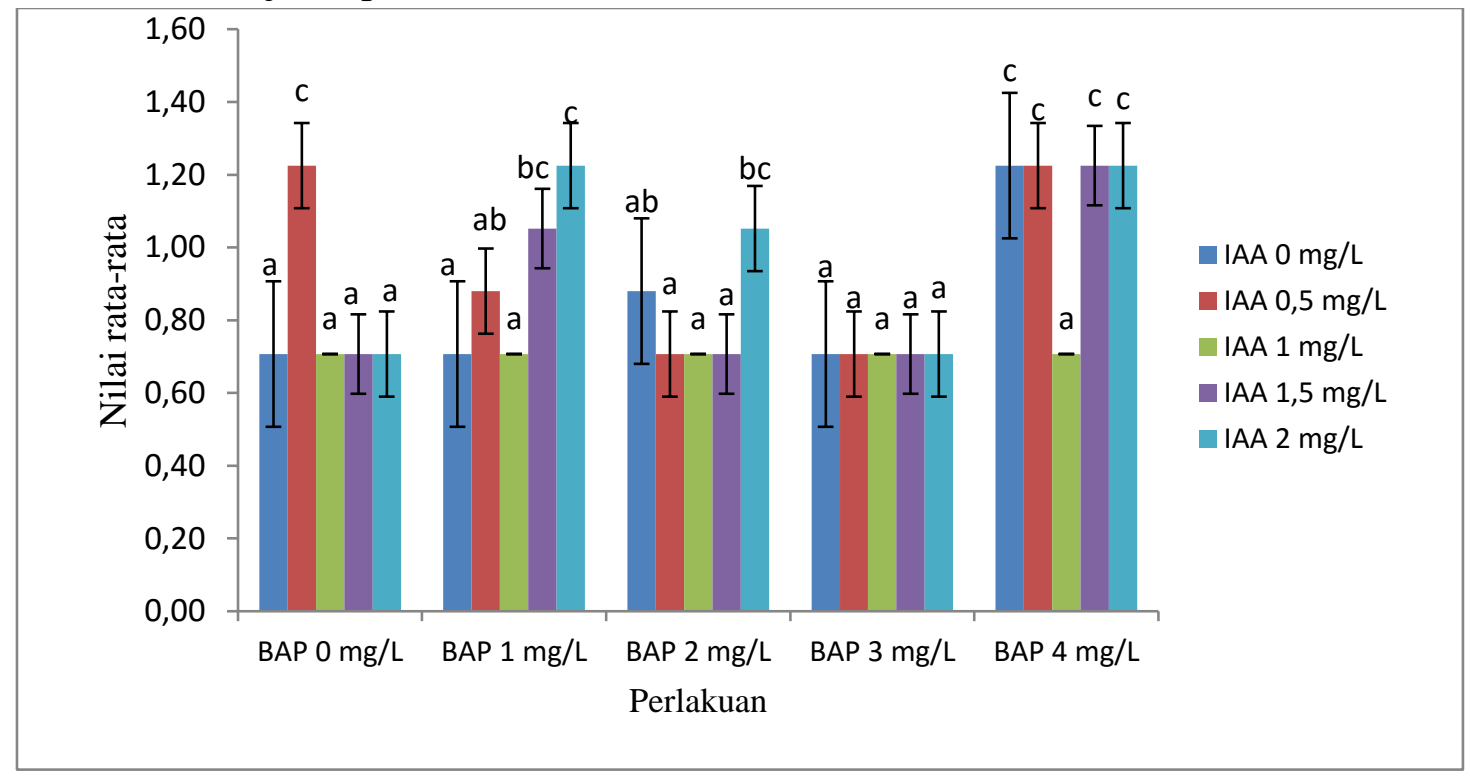

\section{Gambar 2. Histogram Nilai Rata-rata Eksplan Membengkak (Histogram of average} value explants swell)

Hasil analisis sidik ragam menunjukkan bahwa penambahan konsentrasi IAA dan BAP berpengaruh nyata terhadap eksplan ulin yang membengkak. Gambar 2 menunjukkan bahwa IAA $0 \mathrm{mg} / \mathrm{L}+$ BAP $4 \mathrm{mg} / \mathrm{L}$ tidak berbeda nyata dengan IAA 0,5 $\mathrm{mg} / \mathrm{L}+$ BAP $0 \mathrm{mg} / \mathrm{L}$, IAA $0,5 \mathrm{mg} / \mathrm{L}+$ BAP $4 \mathrm{mg} / \mathrm{L}$, IAA $1,5 \mathrm{mg} / \mathrm{L}+$ BAP 1 $\mathrm{mg} / \mathrm{L}$, IAA $1,5 \mathrm{mg} / \mathrm{L}+\mathrm{BAP} 4 \mathrm{mg} / \mathrm{L}$,
IAA $2 \mathrm{mg} / \mathrm{L}+$ BAP $1 \mathrm{mg} / \mathrm{L}$, IAA 2 $\mathrm{mg} / \mathrm{L}+\mathrm{BAP} 2 \mathrm{mg} / \mathrm{L}$, IAA $2 \mathrm{mg} / \mathrm{L}+$ BAP $4 \mathrm{mg} / \mathrm{L}$, namun berbeda nyata dengan perlakuan yang lain. Pembengkakan pada penelitian ini diduga merupakan respon yang mengarah ke pembentukan kalus. Zulkarnain (2009), kalus terbentuk dari keadaan dimana eksplan mengalami pelukaan pada proses penanaman, 
keadaan yang akan terjadi apabila kalus terbentuk yaitu pembengkakan dari eksplan tersebut. Interaksi dan perimbangan antara zat pengatur tumbuh yang diberikan dalam media dan yang diproduksi oleh sel secara endogen menentukan arah perkembangan suatu kultur (Gunawan, 2008).

\section{Eksplan Berkalus}

Pertumbuhan kalus pada eksplan ditandai dengan munculnya tonjolantonjolan kecil yang menyebabkan eksplan membengkak pada jaringan di sekitar luka ke bagian tengah eksplan, kemudian jaringan membesar dan mengembang serta bertambah banyak (Hidayat, 2007). Sari et al. (2013), kalus yang mulai tumbuh ditandai dengan membengkaknya eksplan terutama bagian irisan eksplan yang bersentuhan langsung dengan media dan munculnya bintik-bintik berwarna putih, setelah itu teksturnya menjadi agak kasar (Gambar 2).

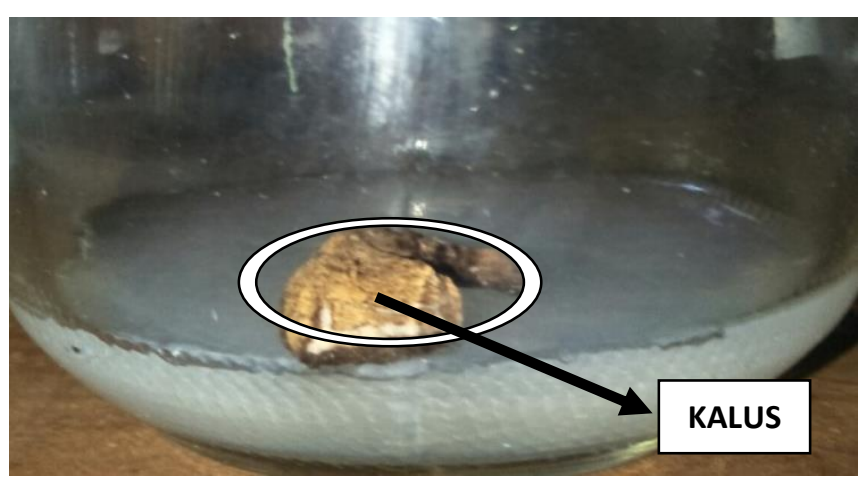

Gambar 3. Eksplan Berkalus (Callus explants)

Hasil pengamatan eksplan berkalus disajikan pada Gambar 4.

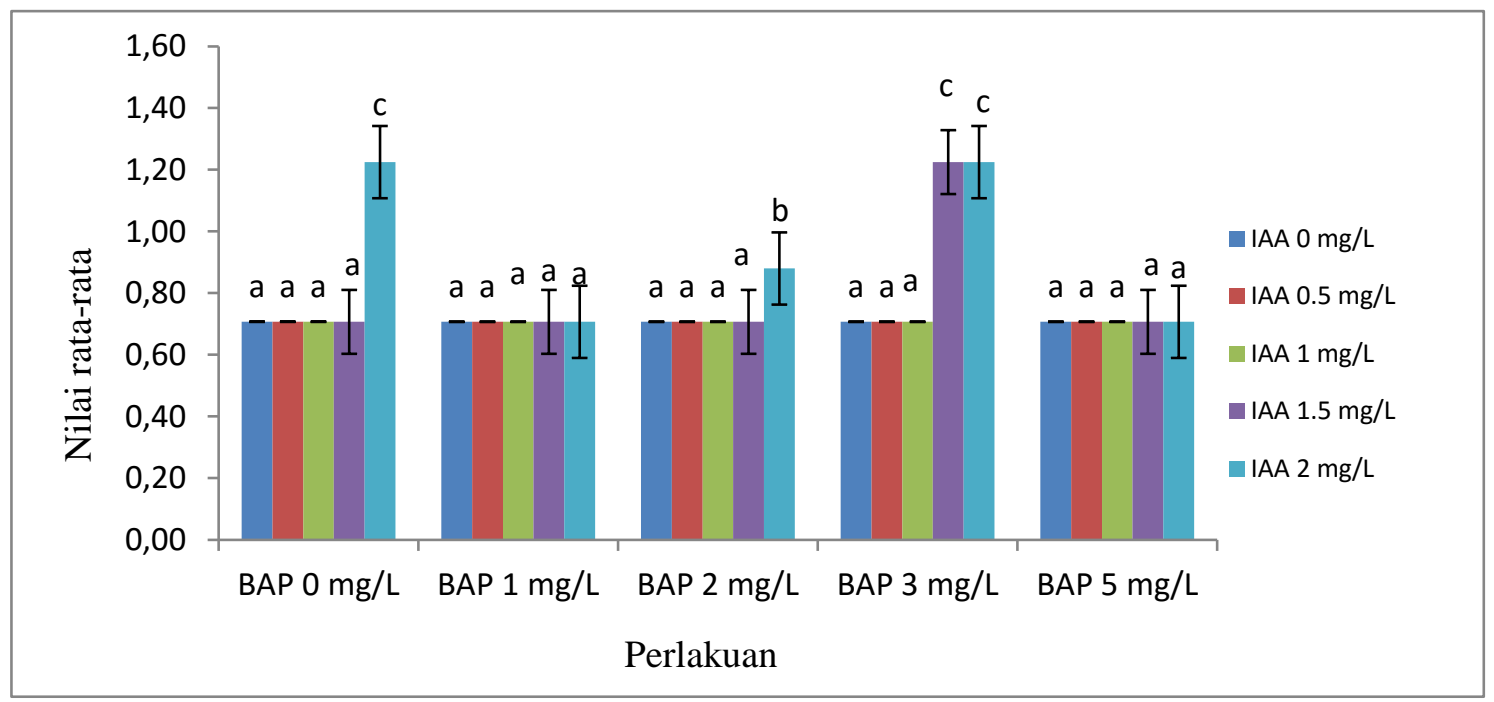

Gambar 4. Histogram Nilai Rata-rata Eksplan Berkalus (Histogram of average callus explants) 
Hasil analisis sidik ragam menunjukkan bahwa konsentrasi IAA dan BAP berpengaruh nyata terhadap eksplan berkalus. Gambar 4 menunjukkan bahwa perlakuan IAA 2 $\mathrm{mg} / \mathrm{L}+$ BAP $0 \mathrm{mg} / \mathrm{L}$, IAA $1,5 \mathrm{mg} / \mathrm{L}+$ BAP $3 \mathrm{mg} / \mathrm{L}$, dan IAA $2 \mathrm{mg} / \mathrm{L}+$ BAP 3 $\mathrm{mg} / \mathrm{L}$ tidak berbeda nyata, namun berbeda nyata terhadap perlakuan yang lainnya. Pada penelitian ini, penambahan konsentrasi IAA $2 \mathrm{mg} / \mathrm{L}+$ BAP $0 \mathrm{mg} / \mathrm{L}$ pada media MS dianggap perlakuan terbaik karena tanpa BAP sudah dapat menginduksi munculnya kalus pada eksplan ulin dengan waktu tercepat yakni 12-13 minggu setelah tanam.

Penambahan auksin dan sitokinin eksogen akan mengubah konsentrasi zat pengatur tumbuh endogen sel. Efektifitas zat pengatur tumbuh auksin maupun sitokinin eksogen bergantung pada konsentrasi hormon endogen dalam jaringan tanaman. Armaniar (2004) pada perlakuan 2,4-D yang rendah $1,5 \mathrm{mg} / \mathrm{L}$ yang dikombinasikan dengan BAP $0,5 \mathrm{mg} / \mathrm{L}$ mampu membentuk kalus Tectona grandis L.F dengan persentase hingga $100 \%$. Kemudian pada penelitian Ajijah et al. (2010), menunjukkan bahwa kombinasi 2,4-D $2 \mathrm{mg} / \mathrm{L}+$ kinetin 0,5 mampu mengahasilkan persentase eksplan buku Vanilla planifolia ANDREW berkalus paling tinggi sebesar $60 \%$.

Kalus yang terbentuk dalam penelitian ini berwarna putih yang mengindikasikan bahwa kalus belum mengandung klorofil. Menurut Fatmawati (2008), warna kalus menginduksi keberadaan klorofil dalam jaringan, semakin hijau warna kalus semakin banyak pula kandungan klorofilnya. Warna terang atau putih dapat menginduksi bahwa kondisi kalus masih cukup baik. Ariati et al. (2012), kalus yang berwarna putih merupakan jaringan embrionik yang belum mengandung kloroplas, tetapi memiliki kandungan butir pati yang tinggi. Rahayu (2003) menyatakan bahwa dengan berlanjutnya pertumbuhan kalus maka akan diikuti dengan perubahan warna kalus.

\section{Hari Muncul Kalus}

Eksplan muncul kalus tercepat pada minggu ke 13 setelah tanam pada perlakuan IAA $2 \mathrm{mg} / \mathrm{L}+0 \mathrm{mg} / \mathrm{L}$ BAP dan terlama minggu ke 19 setelah tanam pada perlakuan IAA 1,5 mg/L + BAP 3 $\mathrm{mg} / \mathrm{L}$. Hari muncul kalus tiap perlakuan dapat dilihat pada histogram pada Gambar 5. 


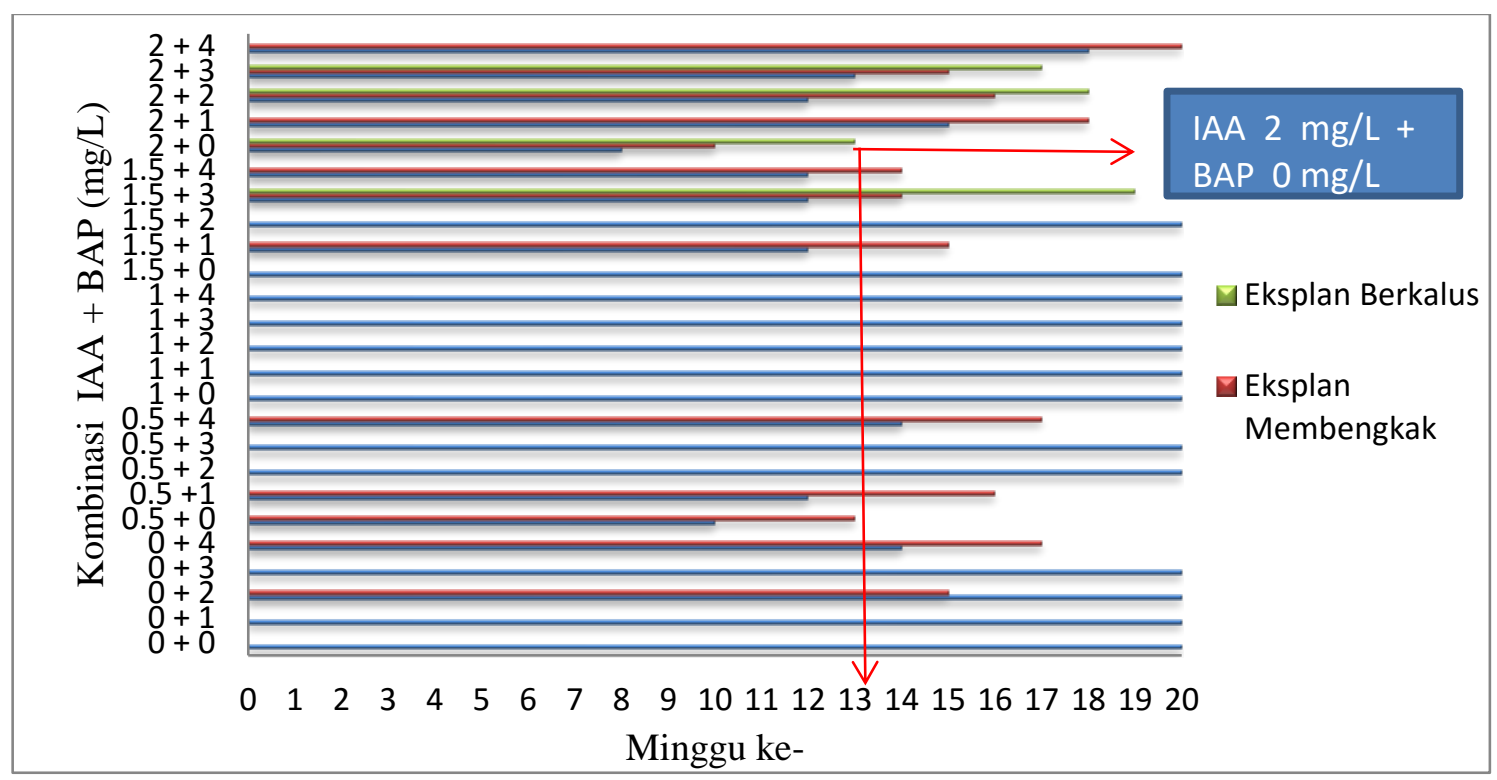

Gambar 5. Histogram Hari Muncul Kalus (Histogram callus day appears)

Terhambatnya pembentukan kalus dikarenakan hormon endogen dan eksogen yang terdapat pada eksplan tidak dapat merangsang pertumbuhan kalus dengan cepat (Indah dan Ermavitalini, 2013). Cepat lambat munculnya kalus dipengaruhi oleh kerja hormon auksin dan sitokinin endogen dan eksogen yang saling berkorelasi. Efektifitas zat pengatur tumbuh auksin maupun sitokinin eksogen bergantung pada konsentrasi hormon endogen dalam jaringan tanaman. Pemberian konsentrasi ZPT yang tidak tepat dapat menghambat pertumbuhan kalus pada eksplan. Kebutuhan akan auksin untuk menginduksi kalus tergantung kadar auksin endogen. Dalam penelitian ini pemberian IAA $2 \mathrm{mg} / \mathrm{L}$ tanpa BAP mampu menginduksi kalus ulin dengan baik dibandingkan dengan penambahan BAP. Auksin digunakan untuk merangsang pembentukan kalus, suspense sel dan organ (Gunawan, 2008), sedangkan sitokinin merangsang pembelahan sel dan diferensiasi tunas adventif dari kalus menjadi organ.

\section{KESIMPULAN}

Kombinasi konsentrasi IAA dan BAP berpengaruh terhadap pertumbuhan eksplan ulin. Eksplan ulin mulai menunjukkan perubahan dimulai dari eksplan membengkak kemudian berkalus. Interaksi konsentrasi IAA dan BAP terbaik untuk eksplan berkalus terjadi pada taraf perlakuan IAA $2 \mathrm{mg} / \mathrm{L}$ + BAP $0 \mathrm{mg} / \mathrm{L}$ dengan waktu tercepat eksplan untuk berkalus yaitu pada minggu ke 12-13 setelah tanam.

\section{DAFTAR PUSTAKA}

Ajijah N, Tasma IM, dan Hadipoentyanti E. 2010. Induksi kalus vanili (Vanilla planifolia ANDREW.) dari eksplan daun dan buku. Buletin Ristri. 1 : 22-23

Ariati, Sri N, Muslimin, Waeniati, Suwastika, Nengah. 2012. Induksi tanaman kakao (Theobroma cacao L.) pada media MS dengan penambahan 2,4-D, BAP dan air 
kelapa. Jurnal Natural Science. 1 (1) : 74-78

Armaniar. 2004. Pengaruh 2,4-D dan BAP pada kultur pucuk jati (Tectona Grandis L.F). Jurnal Penelitian Bidang Ilmu Pertanian. 2 (3) : 41-44

Gunawan LW. 2008. Teknik Kultur Jaringan Tumbuhan. Laboratorium Kultur Jaringan Tumbuhan PAU Bioteknologi. Bogor. Institut Pertanian Bogor.

Hidayat 2007. Induksi pertumbuhan eksplan endosperm ulin dengan IAA dan Kinetine. Agritrop. 26 : $147-152$.

Indah PN, D Ermavitalini. 2013. Induksi kalus daun nyamplung (Calophyllum inophyllum Linn.) pada beberapa kombinasi konsentrasi BAP dan 2,4-D. Jurnal Sains dan Seni Pomits. 2 : 1-6.

Karjadi AK, Buchory A. 2008. Pengaruh komposisi media dasar, penambahan BAP, pikloram terhadap induksi tunas bawang merah. Jurnal Hortikultura. 18 : 1-9.

Lestari EG. 2011. Peranan zat pengatur tumbuh dalam perbanyakan tanaman melalui kultur jaringan. Jurnal Agro Biogen. 7 (1) : 63-68.

Nurhasybi. 2000. Ulin (Eusideroxylon zwageri T. et B.) Atlas Benih
Tanaman Hutan Indonesia Jilid I. Bogor. Balai Teknologi Perbenihan.

Rahayu B, Solichatun, Anggarwulan, Endang. 2003. Pengaruh asam 2,4-diklorofenoksi asetat (2,4-d) terhadap pembentukan dan pertumbuhan kalus serta kanduungan flavonoid kultur kalus Acalypha indica L. Biofarmasi. 1 (1) : 1-6

Ramdan R, Handaji N, Beyahia H, Ibriz M. 2014. Influence of regulator on callus from embryos of five Citrus rootstocks. Journal of Applied Biociences. 73 : 59-65

Sari, Novita, Evie R, Isnawati. 2013. Pengaruh penambahan berbagai konsentrasi 2,4Dikhlorofenoksiasetat (2,4-D) dan 6-Bensil Amino Purin (BAP) pada media MS terhadap tekstur dan warna kalus eksplan batang jati (Tectona grandis Linn. F.). Lentera Bio. 2 (1):70.

Supriyanto, Prakasa KE. 2011. Pengaruh zat pengatur tumbuh Rootone-F terhadap pertumbuhan stek Duabanga mollucana Blume. Jurnal Silvikultur Tropika. 3:5965

Zulkarnain. 2009. Kultur Jaringan Tanaman. Solusi Perbanyakan Tanaman Budi Daya. Jakarta. Bumi Aksara. 